\title{
Effect of insulation on indoor thermal comfort in a detached house with a floor heating system
}

\author{
Qianwen Guo ${ }^{1 *}$, Ryozo Ooka ${ }^{2}$, Wonseok $\mathrm{Oh}^{1}$, Wonjun Choi $^{2}$, Doyun Lee $^{1}$ \\ ${ }^{1}$ Graduate School of Engineering, Department of Architecture, The University of Tokyo, 4-6-1 Komaba, Meguro-ku, Tokyo 153-8505, \\ Japan \\ ${ }^{2}$ Institute of Industrial Science, The University of Tokyo, 4-6-1 Komaba, Meguro-ku, Tokyo 153-8505, Japan
}

\begin{abstract}
Appropriate insulation materials, with unique physical properties and of moderate thickness, are essential for energy savings in residential buildings. However, the impact of thermal insulation on indoor thermal comfort with floor heating systems has not been studied extensively. In this study, simulations of a typical Japanese detached house were conducted with four different thicknesses of insulation material in the walls, ceiling, and floor to estimate the mean air temperature (MAT), mean radiant temperature (MRT), floor temperature, predicted mean vote (PMV) and predicted percentage of dissatisfied (PPD). The results showed that increasing the thickness of thermal insulation increased the MAT and MRT by $1.4-4.0^{\circ} \mathrm{C}$ and $1.3-4.4^{\circ} \mathrm{C}$, respectively. Moreover, as the thickness of the thermal insulation increased, the floor temperature rose and exhibited smaller fluctuations. Finally, it was found that increasing the thickness of thermal insulation improved the indoor thermal comfort environment, as evidenced by an increase in the PMV from -1.0 to 0.3 , and a decrease in the PPD from $25.1 \%$ to $9.5 \%$.
\end{abstract}

\section{Introduction}

With the advantages of high thermal comfort, decreased energy consumption, quiet operation, space saving, and more [1], use of radiant heating $(\mathrm{RH})$ systems has been increasing widely in recent years, not only in residential but also in non-residential buildings worldwide [2]. RH systems are installed in almost all residential buildings in Korea [1], about 30-50\% of new buildings in Germany, Austria, and Denmark [3], and nearly $85 \%$ of rural houses in northern China [4]. Thermal comfort in environments equipped with RH systems is closely associated with the quality of occupants' daily life and is also a hotly debated research topic. There have been a large number of studies on this aspect; for example, the thermal comfort model in radiant environments has been discussed and modified [5][6], field measurements, questionnaires and numerical simulations have been conducted in order to investigate general thermal performance with various RH systems [7][8], Tye-Gingras et al. and Henze et al. focused on the relation between the thermal comfort and energy performance of RH systems [9][10] and thermal comfort in the body parts of occupant and during the night have been considered, as well [11][12]. However, research on thermal insulation and general thermal comfort conditions with $\mathrm{RH}$ system is rarely seen and the corresponding relationship remains uncertain.
Insulation reduces unwanted heat loss or gain in buildings; therefore, the demands of cooling and heating systems are reduced and so does the system size. Meanwhile, periods of thermal comfort without relying on air-conditioning, especially during transition seasons, can be extended. As a result, annual energy costs and bills in buildings and $\mathrm{CO}_{2}$ emissions can be reduced [13], which aids the natural environment.

On the other hand, the heat transfer passing through the roof can be as large as $60 \%$ [14][15], and exterior walls also play an important role since they directly connect to the outside environment. Nearly a third of total energy consumption arises in the building sector (both residential and commercial) in most countries [16]. The total energy consumption is even higher in countries with hot, humid climate, among which approximately $40-60 \%$ of consumption is incurred by air-conditioning systems [17]. Therefore, it is of enormous significance that, by changing insulation properties to adjust the heat exchange between indoor and outdoor spaces, heating and cooling loads of air-conditioning systems can be reduced and a more comfortable indoor environment can be provided.

In this study, a model of a typical Japanese detached house is established; the thickness of insulation added in the ceiling, exterior walls and floor is changed continuously and resulting performance is compared with the reference case of using no insulation material. While observing

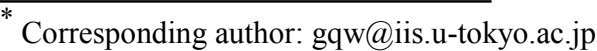




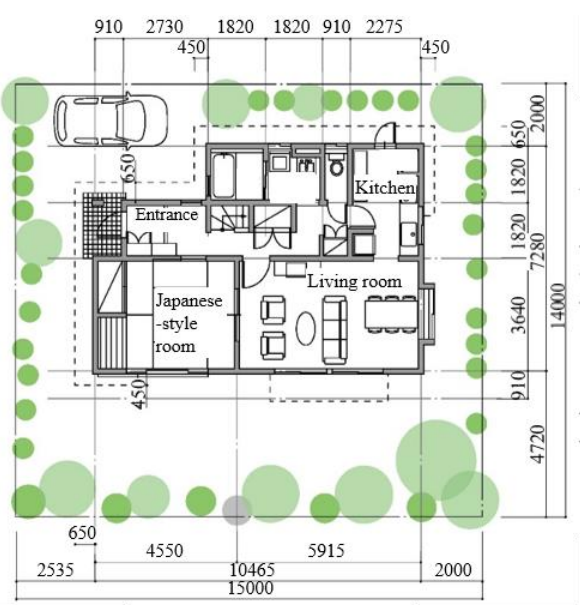

(b) First floor plan

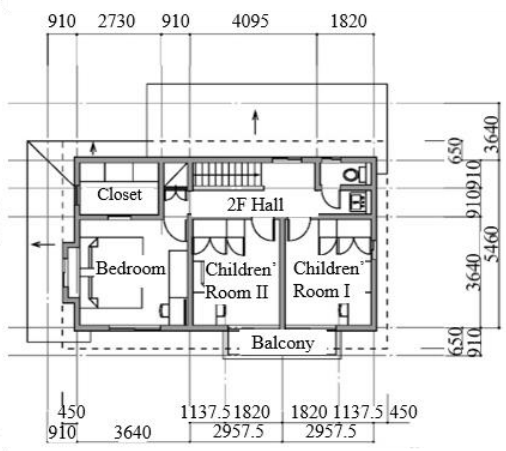

(a) Second floor plan

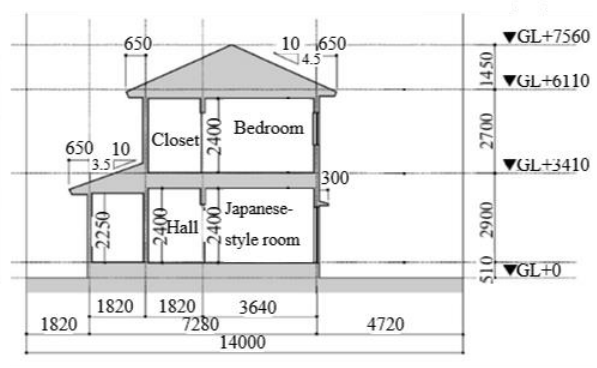

(c) Section plan

Fig. 1. Floor and section plan of the model house

many indicators through simulation, the effect of insulation material thickness on indoor general thermal comfort in a space with $\mathrm{RH}$ system is investigated.

\section{Methodology}

The main purpose of this study is to investigate the effect of thermal insulation material thickness on indoor thermal comfort in a house with a floor heating system. In order to achieve this objective, a Japanese typical detached house [18] was modelled using Sketch-Up version 2017 3D modeling software and a floor heating system was applied in all rooms using OpenStudio version 1.4 .0 building energy modeling software. This system was designed to keep running 24 hours a day during January, February, November, and December, i.e., following the continuous operation mode of the whole residence [18] .

Three cases were considered in this simulation and a model with no insulation was selected as a reference case (Case 0). Based on Case 0, insulation materials were simultaneously added into the exterior walls, ceilings, and floors of rooms. Insulation thickness was changed to 50, 100 and $150 \mathrm{~mm}$. Taking into account the actual situation, occupants, lighting and equipment were adopted as indoor heat gains and ventilation was also considered. Using the Energyplus version 8.0 energy simulation program, mean air temperature (MAT), mean radiant temperature (MRT), and floor temperatures of the rooms were calculated. All these variables are calculated at one represent point for each room. Furthermore, after estimating the indoor wind speed and thermal resistance of people's clothing in winter, two indices reflecting general thermal comfort, predicted mean vote (PMV), and predicted percentage of dissatisfied votes (PPD) were obtained.

According to the Institute for Building Environment and Energy Conservation (IBEC), Japan can be divided into different regions for evaluating energy conservation performance of objective houses appropriately. In the simulation, the model was placed in a region with a moderate climate. It was a two-floor wooden-frameconstruction house, designed based on the most common living arrangement of Japanese families (i.e., two parents with two children) and the climate, had a total area of
120.07 $\mathrm{m}^{2}$, and was $7.56 \mathrm{~m}$ high. The slope of the roof is 4.5:10. The floor plan of the house is shown in Fig. 1. Construction material specifications for the models were set as shown in Table 1. There were ten rooms in the model, of which the living room on the first floor and the three bedrooms (one for the parents and two for the children) on the second floor were places in which people dwelled frequently. The heat loss coefficient ( $Q$ value) of the whole building before and after adding the insulation materials were calculated and are displayed in Table 1, as well. We located the model in Tokyo, which has a humid subtropical climate characterized by hot and humid summers and mild-to-chilly cool winters [19][20]. In terms of the calendar, winter runs from December to February in Tokyo but, in most cases, people living in this climate zone start to use heating equipment from November and continue doing so until February of the following year. The lowest outdoor average temperature usually appears in January [21]. In addition, all weather data in this research were taken from the weather data in Energyplus version 8.0 .

\section{Simulation Conditions}

\subsection{Heat gains}

According to the IBEC, personnel, artificial lighting, and other equipment are considered as internal heat gains [18]. Therefore, in this simulation, all the three were taken into account. In order to understand the heat production states of these components, a survey of daily routines, lifestyles, and living habits of family members was conducted [18]. Then, based on the survey, the schedules for the number of people occupying the living room and the three bedrooms as well as heat generation from lighting and other equipment on weekdays and holidays were created. Moreover, on the basis of the ASHRAE standard [22] combined with real living conditions in the home, the heat generated from one person in the room was set to $70 \mathrm{~W}$, in which circumstance people were assumed to be in a sitting position. Then, by means of multiplying the number of people in the schedule by the heat release value, the total amount of heat generated by occupants was calculated. 
Table 1. Description of the model construction material specification

\begin{tabular}{|c|c|c|c|c|}
\hline Insulation thickness & $\mathrm{t}=0$ & $\mathrm{t}=50 \mathrm{~mm}$ & $\mathrm{t}=100 \mathrm{~mm}$ & $\mathrm{t}=150 \mathrm{~mm}$ \\
\hline $\mathrm{Q}\left(\mathrm{W} / \mathrm{m}^{2} \cdot \mathrm{K}\right)$ & 6.69 & 1.96 & 1.44 & 1.24 \\
\hline \multirow{2}{*}{ Roof } & \multicolumn{4}{|c|}{ Slate $5.2 \mathrm{~mm}$} \\
\hline & \multicolumn{4}{|c|}{ Plywood $12 \mathrm{~mm}$} \\
\hline \multirow[t]{2}{*}{ Ceiling $(2 \mathrm{~F})$} & \multicolumn{4}{|c|}{ Gypsum board $9 \mathrm{~mm}$} \\
\hline & & Glass wool $50 \mathrm{~mm}$ & Glass wool $100 \mathrm{~mm}$ & Glass wool $150 \mathrm{~mm}$ \\
\hline \multirow{5}{*}{$\begin{array}{c}\text { Exterior wall } \\
\text { (Outside to inside) }\end{array}$} & \multicolumn{4}{|c|}{$\begin{array}{l}\text { Siding board } 15 \mathrm{~mm} \\
\end{array}$} \\
\hline & \multicolumn{4}{|c|}{ Aeration layer } \\
\hline & & Glass wool $50 \mathrm{~mm}$ & Glass wool $100 \mathrm{~mm}$ & Glass wool $150 \mathrm{~mm}$ \\
\hline & \multicolumn{4}{|c|}{ A sealed air layer } \\
\hline & \multicolumn{4}{|c|}{ Gypsum board $12 \mathrm{~mm}$} \\
\hline Interior wall & \multicolumn{4}{|c|}{ Gypsum board $12 \mathrm{~mm}$} \\
\hline Floor $(2 \mathrm{~F}) /$ & \multicolumn{4}{|c|}{ Flooring $15 \mathrm{~mm}$} \\
\hline Ceiling $(1 \mathrm{~F})$ & \multicolumn{4}{|c|}{ Plywood $12 \mathrm{~mm}$} \\
\hline \multirow{3}{*}{ Floor $(1 F)$} & \multicolumn{4}{|c|}{ Flooring $15 \mathrm{~mm}$} \\
\hline & \multicolumn{4}{|c|}{ Plywood $12 \mathrm{~mm}$} \\
\hline & & Glass wool $50 \mathrm{~mm}$ & Glass wool $100 \mathrm{~mm}$ & Glass wool $150 \mathrm{~mm}$ \\
\hline Door & \multicolumn{4}{|c|}{$\mathrm{U}=4.65\left(\mathrm{~W} / \mathrm{m}^{2} \cdot \mathrm{K}\right)$} \\
\hline Window & \multicolumn{4}{|c|}{ Double-glazing $\mathrm{U}=2.65\left(\mathrm{~W} / \mathrm{m}^{2} \cdot \mathrm{K}\right)$} \\
\hline
\end{tabular}

\subsection{Material properties}

Even though the material composition of each part of the house was determined, the physical properties of the materials exert great influence on thermal insulation performances. Several important thermophysical properties of the materials, density $\left(\mathrm{kg} / \mathrm{m}^{3}\right)$, conductivity $(\mathrm{W} / \mathrm{m} \cdot \mathrm{K})$, and specific heat $(\mathrm{J} / \mathrm{kg} \cdot \mathrm{K})$ were derived from the official websites of numerous manufacturers and companies [23][24][25][26][27] while the values of thermal/solar/visible absorbptance were set to the default values in OpenStudio. All the properties of material are given in Table 2 .

\subsection{Floor heating system}

A radiant system in the Building Component Library of the OpenStudio named "Low Temperature Radiant Variable Flow," was employed and devised as a floor heating system in the simulation. This is a system of zone equipment intended to model any "radiant system" where water is used to supply/remove energy to/from a building surface (wall, ceiling, or floor) by means of throttling the hot or chilled water flow to the unit [28].

The heat source of the system was a boiler that was heated by natural gas and the outlet water temperature was set to $95^{\circ} \mathrm{C}$. The inlet and outlet water temperatures for the water pump in the floor heating system were set to $40^{\circ} \mathrm{C}$ and $30{ }^{\circ} \mathrm{C}$, respectively, according to the Japan Floor Heating Association guideline for hot water systems [29]. After checking all of the pipe dimensions that can be produced practically, the hydronic tubing's inside diameter in the system was chosen as $0.012 \mathrm{~m}$. The maximum hot water flow flux was set to $0.0002 \mathrm{~m}^{3} / \mathrm{s}$ from the empirical value. Then the heat provided by the hot water can be calculated by the formula shown below.

$$
Q=c \rho q \Delta T
$$

$Q$ : heat energy $(\mathrm{J} / \mathrm{s}), c$ : specific heat $(\mathrm{J} / \mathrm{kg} \cdot \mathrm{K})$

$\rho$ : density of the substance $\left(\mathrm{kg} / \mathrm{m}^{3}\right)$

$q$ : flow flux of the substance $\left(\mathrm{m}^{3} / \mathrm{s}\right)$

$\Delta T$ : change in temperature $(\mathrm{K})$

Considering that the heat generated by the floor is not transferred completely upwards, the assumed radiation rate downward was $15 \%$ [29] and the amount of heat becomes $7,140 \mathrm{~W}$. It is obvious that validation of whether the settings above are correct is necessary. In Tokyo, the heat load is about $80 \mathrm{~W} / \mathrm{m}^{2}$ in winter and the laying rate of a floor heating system is calculated at $75 \%$ [29], so the total heat load of the room is about $7,204 \mathrm{~W}$ $(120.07 \times 80 \times 0.75)$. This result shows that the settings we used were appropriate. Furthermore, the length of tubing in the floor heating system was also determined by the production specifications, i.e., $5 \mathrm{~m} / \mathrm{m}^{2}$; thus, the total length of tubing was $450 \mathrm{~m}(120.07 \times 5 \times 0.75)$.

Table 2. Material physical properties

\begin{tabular}{ccccccc}
\hline Material & Slate & Plywood & Gypsum board & Siding board & Flooring & Glass wool \\
\hline Thickness $(\mathrm{m})$ & 0.0052 & 0.012 & $0.009 / 0.012$ & 0.015 & 0.015 & \\
\hline Conductivity $(\mathrm{W} / \mathrm{m} \cdot \mathrm{K})$ & 0.96 & 0.16 & 0.22 & 0.21 & 0.15 & 0.038 \\
\hline Density $\left(\mathrm{kg} / \mathrm{m}^{3}\right)$ & 1600 & 500 & 800 & 1100 & 700 & 16 \\
\hline Specific Heat $(\mathrm{J} / \mathrm{kg} \cdot \mathrm{K})$ & 1520 & 716 & 904 & 1679 & 649 & 840 \\
\hline Thermal Absorptance & 0.9 & 0.9 & 0.9 & 0.9 & 0.9 & 0.9 \\
\hline Solar Absorptance & 0.7 & 0.7 & 0.7 & 0.7 & 0.7 & 0.7 \\
\hline Visible Absorptance & 0.7 & 0.7 & 0.7 & 0.7 & 0.7 & 0.7 \\
\hline
\end{tabular}


Table 3. Average mean air temperature during the simulation

\begin{tabular}{|c|c|c|c|c|c|c|c|}
\hline \multirow[b]{2}{*}{ Room } & \multicolumn{4}{|c|}{ Mean air temperature $\left({ }^{\circ} \mathrm{C}\right)$} & \multirow{2}{*}{$\begin{array}{c}\text { Increase } \\
\text { between Case } 1 \\
\text { and Case } 0\left({ }^{\circ} \mathrm{C}\right)\end{array}$} & \multirow{2}{*}{$\begin{array}{c}\text { Increase } \\
\text { between Case } 2 \\
\text { and Case } 0\left({ }^{\circ} \mathrm{C}\right)\end{array}$} & \multirow{2}{*}{$\begin{array}{c}\text { Increase } \\
\text { between Case } 3 \\
\text { and Case } 0\left({ }^{\circ} \mathrm{C}\right)\end{array}$} \\
\hline & $\begin{array}{c}\text { Case } 0 \\
(\mathrm{t}=0)\end{array}$ & $\begin{array}{l}\text { Case 1 } \\
(\mathrm{t}=50)\end{array}$ & $\begin{array}{c}\text { Case 2 } \\
(\mathrm{t}=100)\end{array}$ & $\begin{array}{c}\text { Case } 3 \\
(t=150)\end{array}$ & & & \\
\hline Living Room & 17.5 & 18.9 & 19.6 & 20.1 & 1.4 & 2.1 & 2.6 \\
\hline Bed Room & 17.5 & 19.1 & 19.9 & 20.6 & 1.6 & 2.4 & 3.1 \\
\hline Children's Room I & 17.6 & 19.0 & 19.9 & 20.6 & 1.4 & 2.3 & 3.0 \\
\hline Children's Room II & 18.5 & 20.4 & 21.6 & 22.5 & 1.9 & 3.1 & 4.0 \\
\hline
\end{tabular}

\subsection{Operating mode}

There are two types of heating system operating modes in Tokyo: continuous operation in the whole house and intermittent operation in parts of the house. Although the second operating mode may be closer to the case of real life, the purpose of this study was to explore the relationship between the thickness of insulation material and the thermal comfort of a house with a floor heating system; the basis for this is to create an indoor environment with continuous floor heating, so the first operating mode was selected.

\subsection{Ventilation and infiltration}

Regarding the internal space of the house, air change rate was set to 0.5 times per hour, corresponding to volumetric air flow rate of $160 \mathrm{~m}^{3} / \mathrm{h}$. Infiltration was not considered.

The thickness of the insulation material $(t)$ was changed from $50 \mathrm{~mm}$ (Case 1) to $100 \mathrm{~mm}$ (Case 2) and $150 \mathrm{~mm}$ (Case 3). During the simulation, it was assumed that the doors of all the rooms were closed all the time, and the thickness of the insulation material added into the ceilings, exterior walls, and floors was varied continuously. Additionally, the overall heat transfer coefficient ( $U$ value) of the internal walls was assumed to be constant. The time step was set to ten minutes. Based on the conditions above, simulations were conducted.

\section{Discussion of Results}

\subsection{Mean air temperature and mean radiant temperature}

The variation of air temperature in the room is characterized by either the mean air temperature (MAT) or the operative temperature (OT). OT is defined as the average of the mean radiant temperature (MRT) and ambient temperatures weighted by their respective heat transfer coefficients [30].

A comparison was made to determine the differences Table 4. Average mean radiant temperature during the simulation

\begin{tabular}{|c|c|c|c|c|c|c|c|}
\hline \multirow{3}{*}{ Room } & \multicolumn{4}{|c|}{ Mean radiant temperature $\left({ }^{\circ} \mathrm{C}\right)$} & \multirow{3}{*}{$\begin{array}{c}\text { Increase } \\
\text { between Case } 1 \\
\text { and Case } 0\left({ }^{\circ} \mathrm{C}\right)\end{array}$} & \multirow{3}{*}{$\begin{array}{c}\text { Increase } \\
\text { between Case } 2 \\
\text { and Case } 0\left({ }^{\circ} \mathrm{C}\right)\end{array}$} & \multirow{3}{*}{$\begin{array}{c}\text { Increase } \\
\text { between Case } 3 \\
\text { and Case } 0\left({ }^{\circ} \mathrm{C}\right)\end{array}$} \\
\hline & Case 0 & Case 1 & Case 2 & Case 3 & & & \\
\hline & $(\mathrm{t}=0)$ & $(\mathrm{t}=50)$ & $(\mathrm{t}=100)$ & $(\mathrm{t}=150)$ & & & \\
\hline Living Room & 17.0 & 18.3 & 19.2 & 20.0 & 1.3 & 2.2 & 3.0 \\
\hline Bed Room & 16.9 & 18.7 & 19.7 & 20.3 & 1.8 & 2.8 & 3.4 \\
\hline Children's Room I & 17.0 & 18.7 & 19.6 & 20.3 & 1.7 & 2.6 & 3.3 \\
\hline Children's Room II & 17.8 & 20.0 & 21.3 & 22.2 & 2.2 & 3.5 & 4.4 \\
\hline
\end{tabular}

between these two parameters. The results indicate that the difference between means of MAT and OT during the four months are $0.0,0.0,0.2,0.0^{\circ} \mathrm{C}$, respectively. Since the aim of this research is to focus on trends of indoor thermal comfort with varying thickness of the insulation materials but not detailed values and since the effect of radiant heat transfer is reflected separately by MRT, the MAT was selected as an indicator of indoor temperature. Table 3 and 4 show the results of MAT and MRT in the four typical rooms during the simulation, which ranged from 17.5 to $22.5^{\circ} \mathrm{C}$ and from 16.9 to $22.2^{\circ} \mathrm{C}$, respectively. Among them, the children's room (II) with only one exterior wall presented the highest MAT and MRT while the living room with two exterior walls and large windows on the first floor showed the lowest values. Regardless of the room, the average value of MAT was higher than that of the MRT. This was because, in Energyplus, MRT is calculated through the indoor surface area multiplied by the emissivity weighted average of the room's inside surface temperatures, where emissivity is the thermal absorptance of the inside material layer of each surface and MAT is the average of the air temperatures in a zone using a "well-stirred" heat balance model [28]. In other words, MRT is affected by the temperatures of surfaces within a room.

Secondly, regardless of the location of the room, as the thickness of the insulation increased, both MAT and MRT gradually increased. However, these two quantities did not exhibit a linear relationship. When the thickness of the insulation material was changed from 0 to $50 \mathrm{~mm}$, MAT and MRT increased significantly and the monthly average value increases by about 1.4 to $1.9^{\circ} \mathrm{C}$ and 1.3 to $2.2^{\circ} \mathrm{C}$, respectively, but when the thickness of the insulation material continued to increase from $50 \mathrm{~mm}$ to $100 \mathrm{~mm}$ and then $150 \mathrm{~mm}$, the increases in MAT was only $0.7-1.2^{\circ} \mathrm{C}$ and $0.5-0.9^{\circ} \mathrm{C}$, respectively, while MRT increased by only $0.9-1.3^{\circ} \mathrm{C}$ and $0.6-0.9^{\circ} \mathrm{C}$, respectively. in the middle of the house; it had minimal contact with the outside (through only one exterior wall) and the floor heating system was installed in the room and in rooms to its left and right and directly below. Thus, a relatively ideal stable indoor environment was created by the floor heating system in the children's room (II).
Among the four rooms, the children's room (II) was nearly 


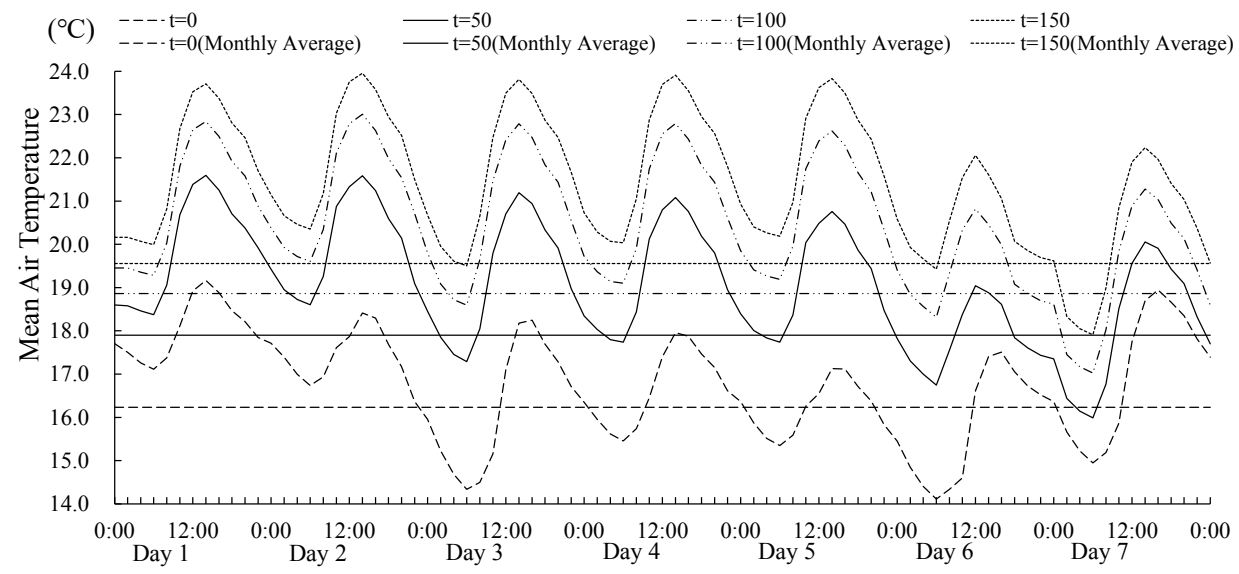

Fig. 2. The daily results of MAT in the coldest week and the mean of January in children's room (II)

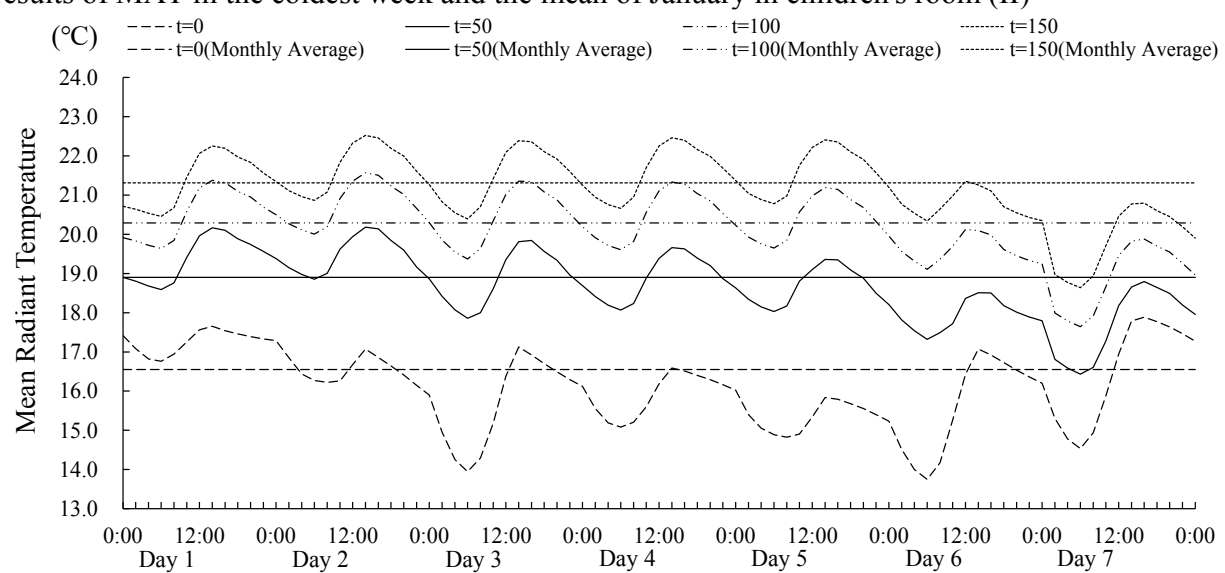

Fig. 3. The daily results of MRT in the coldest week and the mean of January in children's room (II)

The outside air temperature of January is from $0.2^{\circ} \mathrm{C}$ to $13.2^{\circ} \mathrm{C}$, the average is $6.3^{\circ} \mathrm{C}$, and the temperature range during the coldest week is $0.7^{\circ} \mathrm{C}-12.0^{\circ} \mathrm{C}$. The average MAT and MRT values during January and daily results in the coldest week of January in children's room (II) are presented in Fig. 2 and 3. The trend of MAT was clearly coincident with the variation of sunlight both with and without the insulation materials. The lowest MAT appeared at around 6 am and the highest at around $2 \mathrm{pm}$. The same trend appeared for MRT, as well. In addition, as with the variation of average values for MAT, the thicker the thickness of the insulating material, the greater the daily MAT; however, this was not a linear relationship. The same was found for the MRT. These results show that both MAT and MRT in the rooms can be raised by increasing the thickness of the insulation material to some degree.

\subsection{Floor temperature}

For a floor heating system, heating performance, local and general comfort in the room are closely related to the floor temperature. The maximum and minimum temperatures for the floor during the simulation are listed in Table 5. From the table, the highest temperature of the floor was about $22.5-24.1{ }^{\circ} \mathrm{C}$, the lowest temperature was $19.1-21.5^{\circ} \mathrm{C}$, and the maximum difference between the highest and lowest temperatures was $4.4^{\circ} \mathrm{C}$. This proved that there was no significant fluctuation in floor temperature. Moreover, in the case without insulation material (Case 0), the difference between the highest and lowest floor temperatures was distinctly large. When the thickness of the insulation material was continuously changed from $50 \mathrm{~mm}$ to 150 $\mathrm{mm}$, the difference between the maximum and minimum values of the floor temperature in all four rooms was gradually reduced, revealing a more stable indoor environment. Among the rooms, the room with the least contact with the outside air, i.e., with the best insulation effect (children's room (II)), floor temperature apparently changed as the thickness of the insulation material increased.

Table 5. Maximum and minimum values of floor temperature during the simulation

\begin{tabular}{|c|c|c|c|c|c|}
\hline \multirow{3}{*}{ Room } & \multicolumn{4}{|c|}{ The maximum and minimum floor Temperature $\left({ }^{\circ} \mathrm{C}\right)$} & \multirow{3}{*}{$\begin{array}{l}\text { Maximum difference } \\
\text { between MAX/MIN } \\
\left({ }^{\circ} \mathrm{C}\right)\end{array}$} \\
\hline & Case 0 & Case 1 & Case 2 & Case 3 & \\
\hline & $(\mathrm{t}=0)$ & $(\mathrm{t}=50)$ & $(\mathrm{t}=100)$ & $(\mathrm{t}=150)$ & \\
\hline Living Room & $22.9 / 19.1$ & $22.4 / 20.0$ & $22.7 / 19.5$ & $22.5 / 19.7$ & 3.8 \\
\hline Bed Room & $22.9 / 19.1$ & $23.4 / 21.3$ & $23.5 / 20.5$ & $23.3 / 21.0$ & 3.8 \\
\hline Children's Room I & $24.1 / 19.7$ & $23.4 / 21.5$ & $23.6 / 20.3$ & $23.4 / 20.8$ & 4.4 \\
\hline Children's Room II & $23.3 / 19.2$ & $22.9 / 19.2$ & $22.4 / 20.6$ & $22.1 / 20.6$ & 4.1 \\
\hline
\end{tabular}




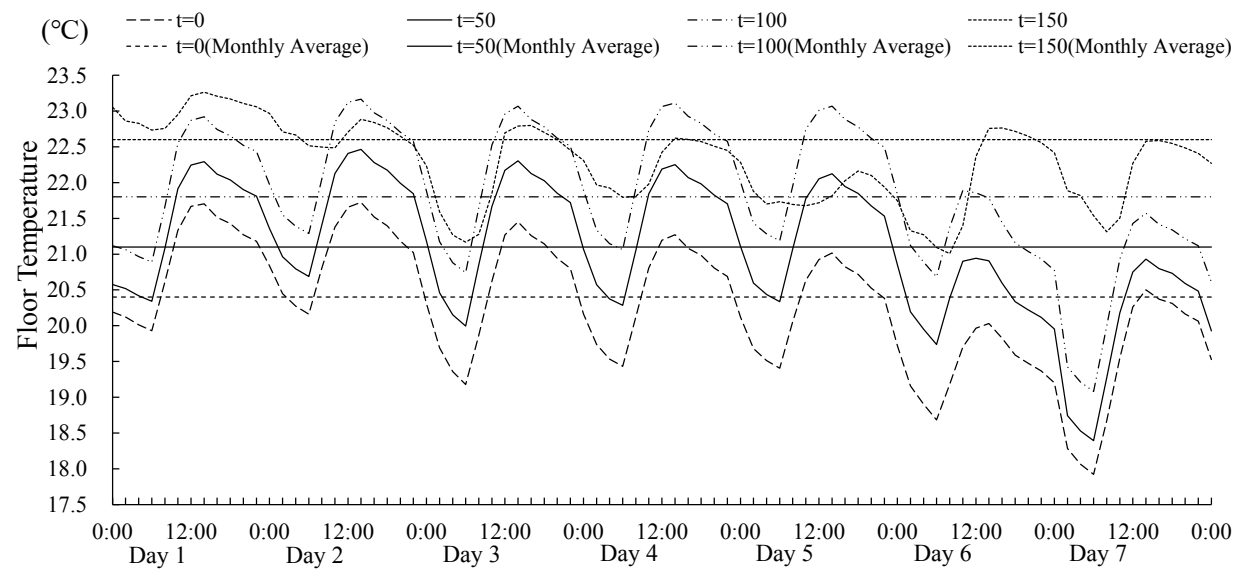

Fig. 4. The daily results of floor temperature in the coldest week and the mean of January in children's room (II)

Table 6. Average predicted mean vote during the simulation

\begin{tabular}{|c|c|c|c|c|c|c|c|c|}
\hline \multirow{3}{*}{ Room } & \multicolumn{4}{|c|}{ Predicted mean vote } & \multirow{2}{*}{\multicolumn{4}{|c|}{$\begin{array}{c}\text { Percentage of PMV in recommended } \\
\text { thermal state of ISO }(\%)\end{array}$}} \\
\hline & Case 0 & Case 1 & Case 2 & Case 3 & & & & \\
\hline & $(\mathrm{t}=0)$ & $(\mathrm{t}=50)$ & $(\mathrm{t}=100)$ & $(\mathrm{t}=150)$ & $(t=0)$ & $(\mathrm{t}=50)$ & $(\mathrm{t}=100)$ & $(t=150)$ \\
\hline Living Room & -1.0 & -0.5 & -0.4 & -0.2 & 20 & 45 & 62 & 74 \\
\hline Bed Room & -0.7 & -0.4 & -0.2 & -0.1 & 27 & 59 & 71 & 75 \\
\hline Children's Room I & -0.7 & -0.4 & -0.2 & -0.1 & 28 & 47 & 63 & 70 \\
\hline Children's Room II & -0.5 & -0.1 & 0.1 & 0.3 & 45 & 81 & 81 & 70 \\
\hline
\end{tabular}

Fig. 4 shows the daily floor temperature of the children's room (II) during the coldest week of January and the monthly averages. These results match the results above; that is, the floor temperature increased when insulation was added compared to situations without insulation material. Additionally, as the thickness of insulation material increased, the floor temperature also increased. Moreover, it appears that the trend of daily floor temperature is consistent with the variation of sunlight, as for MAT and MRT. However, as the thickness of the insulation material increased, the time at which the lowest and highest floor temperatures appeared each day were slightly delayed. In addition, unlike the change in MAT or MRT, both the daily variation and monthly average of the floor temperature present a linear relationship with the thickness of the thermal insulation material. The floor temperature increased by about $0.7^{\circ} \mathrm{C}$ for every $50 \mathrm{~mm}$ increase in thermal insulation material thickness.

\subsection{Predicted mean vote and predicted percentage of dissatisfied votes}

Based on the Fanger comfort model, two indicators that reflect general thermal comfort, predicted mean vote (PMV), and predicted percentage of dissatisfied votes
(PPD) were established. The PMV is to predict the mean value of the thermal votes of a large group of people exposed to the same environment, and the PPD is to predict is to predict the percentage of thermally dissatisfied people who feel too cool or too warm. Caculating the PMV using equations (2) [31].

$P M V=\left[0.303 * \exp \left(-0.036^{*} M\right)+0.028\right]^{*}$

$\left\{(M-W)-3.05^{*} 10^{-3 *}\left[5733-6.99 *(M-W)-p_{a}\right]-\right.$

$0.42 *[(M-W)-58.15]-1.7 * 10^{-5 *} M^{*}\left(5867-p_{a}\right)$

$0.0014 * M^{*}\left(34-t_{a}\right)-3.96 * 10^{-8 *} f_{c l} *$

$\left.\left.\left[\left(t_{c l}+273\right)^{4}-\left(t_{r}+273\right)^{4}\right\}-f_{c l} * h_{c} *\left(t_{c l}-t_{a}\right)\right]\right\}$

$M$ : metabolic rate, in watts per square metre $\left(\mathrm{W} / \mathrm{m}^{2}\right)$

$W$ : effective mechanical power, in watts per square metre $\left(\mathrm{W} / \mathrm{m}^{2}\right)$

$I_{c l}$ : clothing insulation, in square metre kelvin per watt $\left(\mathrm{m}^{2} \cdot \mathrm{K} / \mathrm{W}\right)$

$f_{c l}$ : clothing surface area factor

$t_{a}$ :air temperature, in degrees Celsius $\left({ }^{\circ} \mathrm{C}\right)$

$t_{r}$ : mean radiant temperature, in degrees Celsius $\left({ }^{\circ} \mathrm{C}\right)$

$v_{a r}$ : relative air velocity, in metres per second $(\mathrm{m} / \mathrm{s})$

$p_{a}$ : water vapour partial pressure, in pascals $(\mathrm{Pa})$

$h_{c}$ : convective heat transfer coefficient, in watts per square metre kelvin $\left[\mathrm{W} /\left(\mathrm{m}^{2} \cdot \mathrm{K}\right)\right]$

$t_{c l}$ : clothing surface temperature, in degrees Celsius $\left({ }^{\circ} \mathrm{C}\right)$

Table 7. Average predicted percentage of dissatisfied vote during the simulation

\begin{tabular}{|c|c|c|c|c|c|c|c|}
\hline \multirow[t]{2}{*}{ Room } & \multicolumn{4}{|c|}{$\begin{array}{l}\text { Predicted percentage of dissatisfied } \\
\text { vote }(\%)\end{array}$} & \multirow{2}{*}{$\begin{array}{c}\text { Decrease } \\
\text { between Case } 1 \\
\text { and Case } 0(\%)\end{array}$} & \multirow{2}{*}{$\begin{array}{c}\text { Decrease } \\
\text { between Case } 2 \\
\text { and Case } 0(\%)\end{array}$} & \multirow{2}{*}{$\begin{array}{c}\text { Decrease } \\
\text { between Case } 3 \\
\text { and Case } 0(\%)\end{array}$} \\
\hline & $\begin{array}{c}\text { Case } 0 \\
(\mathrm{t}=0)\end{array}$ & $\begin{array}{l}\text { Case } 1 \\
(\mathrm{t}=50)\end{array}$ & $\begin{array}{c}\text { Case 2 } \\
(\mathrm{t}=100)\end{array}$ & $\begin{array}{c}\text { Case } 3 \\
(\mathrm{t}=150)\end{array}$ & & & \\
\hline Living Room & 25.1 & 13.6 & 11.4 & 9.3 & 49 & 55 & 64 \\
\hline Bed Room & 19.5 & 11.2 & 9.2 & 8.4 & 42 & 53 & 57 \\
\hline Children's Room I & 19.4 & 11.4 & 9.3 & 8.5 & 41 & 52 & 56 \\
\hline Children's Room II & 13.6 & 7.9 & 7.9 & 9.5 & 42 & 42 & 30 \\
\hline
\end{tabular}




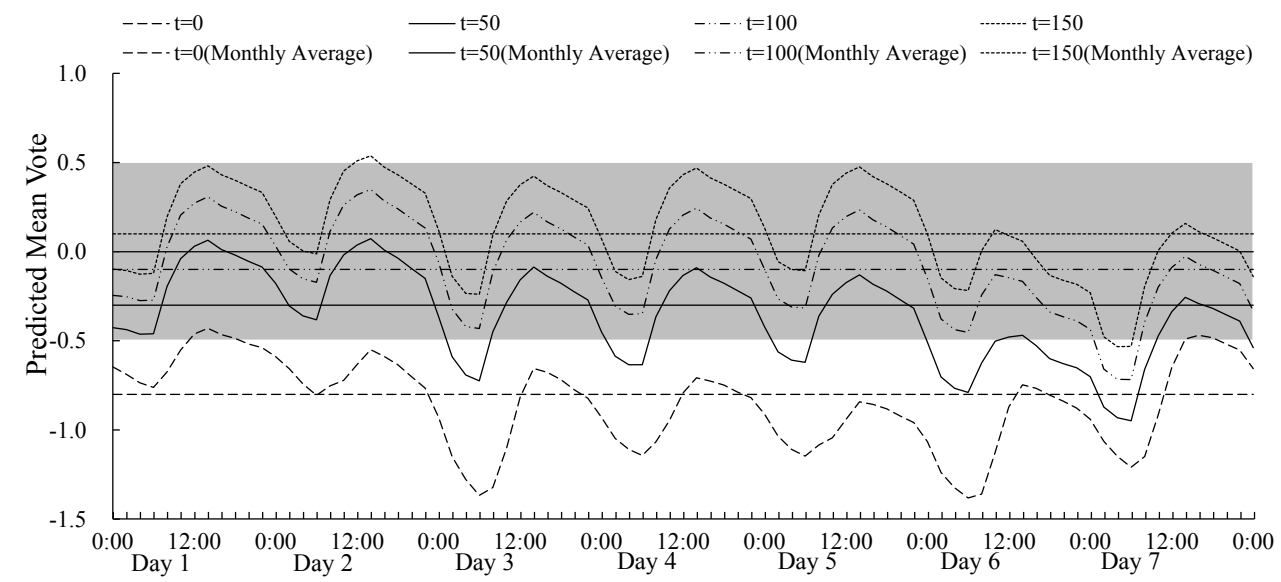

Fig. 5. The daily results of PMV in the coldest week and the mean of January in children's room (II)

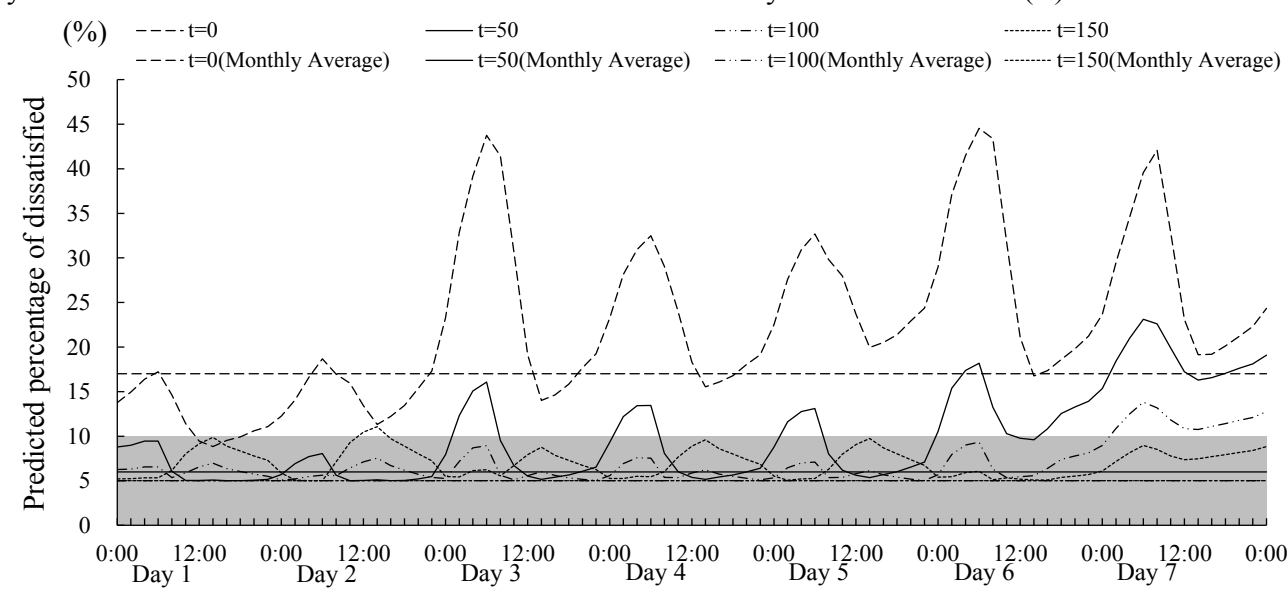

Fig. 6. The daily results of PPD in the coldest week and mean of January in children's room (II)

The PMV and PPD during simulation are given in Table 6 and 7. The maximum value of PMV was 0.3 and the minimum value was -1.0 while the corresponding PPD values were $9.5 \%$ and $25.1 \%$. In the four rooms, the highest PMV and lowest PPD values appear in the children's room (II) with a respective ideal floor heating environment. The lowest PMV and highest PPD were in the living room with large exterior walls and windows. The results for the remaining two rooms were similar. On the other hand, regardless of the locations of the rooms, in Case 0 without insulation material, PMV was the lowest and PPD highest; that is, the rooms were coldest and most uncomfortable. As the thickness of the insulation material was continuously increased, the PMV values of all rooms began to increase and, at the same time, the corresponding values of PPD began to decrease.

In the children's room (II), when the thickness of the insulation was increased to $100 \mathrm{~mm}$ and then to $150 \mathrm{~mm}$, the values of PMV became positive, i.e., the room became warm from a state of being cold. In addition, the desired thermal environment for a space is recommend by ISO through prescribing a maximum percentage dissatisfied for the body as a whole (PPD), which is $\mathrm{PPD}<10 \% \quad(0.5<\mathrm{PMV}<0.5)$. Thus the percentage of PMV values during the simulation within the recommended range is calculated and listed in Table 6 . From this result, it can be seen that this percentage increased significantly with the increase of insulation material thickness and the maximum increase reached $54 \%$ (in the living room). In Table 7 , the percentage of the PPD decrease value after adding the insulation material compared to the case without the insulation material is presented. The range of the decrease was 30$64 \%$. Among them, except for the children's room (II), the percentage of PPD decrease in the remaining three rooms gradually increased; in other words, the thermal comfort in these rooms rose rapidly.

Fig. 5 and 6 show the results of PMV and PPD for the coldest week and mean of January of the children's room (II). At first, the variation of daily PMV and PPD appeared to be affected by sunlight. That is, in the afternoon when sunshine was abundant and the outdoor temperature was high, the PMV value increased and the corresponding PPD decreased whereas the opposite situation appeared in the early morning. Secondly, as with the average results shown in the tables, we found that the PMV values in cases with insulation material increased significantly compared with that in the case without insulation and the PPD value also showed a noticeable decrease. However, this change did not show a linear relationship; that is, when the thickness of the insulation material increased to $50 \mathrm{~mm}$, the PMV value increased significantly but, as the thickness continued to increase from $50 \mathrm{~mm}$ to $100 \mathrm{~mm}$ and then to $150 \mathrm{~mm}$, the PMV continued to increase but at a successively smaller rate. The trend of PPD showed the same feature. This result means that it is not workable to adjust the indoor thermal sensation and thermal comfort by 
increasing the thickness of the insulation material indefinitely. The shaded portion in the figure denotes $-0.5<\mathrm{PMV}<0.5 \quad(\mathrm{PPD}<10 \%)$ for the desirable value recommended by ISO [31]. The values of PMV and PPD for Case 0 fell completely outside of this area whereas Cases 2 and 3 showed results almost within the zone. When the thickness was $50 \mathrm{~mm}$, PMV and PPD were outside of this range when the temperature was relatively low, from midnight to early morning. In addition, we also found that, except for the children's room (II) where the PPD value changed from a negative number to a positive number, as the thickness of the insulation material increased, the fluctuations of PPD gradually became smaller and flatter.

\section{Conclusion}

In order to investigate the influence of the thickness of the insulation material on indoor thermal comfort with a floor heating system, a model of a typical Japanese detached house was created. By changing the thickness of the insulation material added to the exterior walls, ceilings, and floors with the help of simulation software, the relationship between the thickness of the insulation material and several parameters expressing the thermal comfort of the room were examined. These parameters included mean air temperature (MAT), mean radiant temperature (MRT), floor temperature, predicted mean vote (PMV), and predicted percentage of dissatisfied votes (PPD).

Results showed that, as the thickness of the insulation increased, both the MAT and MRT gradually increased. However, these two quantities did not show a linear relationship. The floor temperature increased when insulation was added compared to the situation without insulation material. Additionally, as the thickness of the insulation material increased, the floor temperature also increased. Furthermore, the PMV value of the cases with insulation material increased significantly compared with the case without insulation and the PPD value also showed a noticeable decrease. However, this change also did not show a linear relationship. Clearly, indoor thermal comfort can be improved by increasing the thickness of the insulation material to some degree.

\section{References}

[1] K. N. Rhee and K. W. Kim, "A 50 year review of basic and applied research in radiant heating and cooling systems for the built environment," Build. Environ., vol. 91, pp. 166-190, 2015.

[2] K. N. Rhee, B. W. Olesen, and K. W. Kim, "Ten questions about radiant heating and cooling systems," Build. Environ., vol. 112, pp. 367-381, 2017.

[3] B. Olesen, "Radiant floor heating in theory and practice - ProQuest," Ahrae, vol. 19, no. July, pp. 19-24, 2002.

[4] Z. Zhuang, Y. Li, B. Chen, and J. Guo, "Chinese kang as a domestic heating system in rural northern China-A review," Energy Build., vol. 41, no. 1, pp. 111-119, 2009.

[5] L. Z. Zhang and J. L. Niu, "Indoor humidity behaviors associated with decoupled cooling in hot and humid climates," Build. Environ., vol. 38, no. 1, pp. 99-107, 2003.

[6] L. Schellen, M. G. L. C. Loomans, B. R. M. Kingma, M. H. de Wit, A. J. H. Frijns, and W. D. van Marken Lichtenbelt, "The use of a thermophysiological model in the built environment to predict thermal sensation: Coupling with the indoor environment and thermal sensation," Build. Environ., vol. 59, pp. 10-22, 2013.

[7] W. Zeiler and G. Boxem, "Effects of thermal activated building systems in schools on thermal comfort in winter," Build. Environ., vol. 44, no. 11, pp. 2308-2317, 2009.

[8] J. A. Myhren and S. Holmberg, "Flow patterns and thermal comfort in a room with panel, floor and wall heating," Energy Build., vol. 40, no. 4, pp. 524-536, 2008.

[9] M. Tye-Gingras and L. Gosselin, "Comfort and energy consumption of hydronic heating radiant ceilings and walls based on CFD analysis," Build. Environ., vol. 54, pp. 1-13, 2012.

[10] G. P. Henze, C. Felsmann, D. E. Kalz, and S. Herkel, "Primary energy and comfort performance of ventilation assisted thermo-active building systems in continental climates," Energy Build., vol. 40, no. 2, pp. 99-111, 2008.

[11] C. Leung and H. Ge, "Sleep thermal comfort and the energy saving potential due to reduced indoor operative temperature during sleep," Build. Environ., vol. 59, pp. 91-98, 2013.

[12] L. Schellen, S. Timmers, M. Loomans, E. Nelissen, J. L. M. Hensen, and W. Van Marken Lichtenbelt, "Downdraught assessment during design: Experimental and numerical evaluation of a rule of thumb," Build. Environ., vol. 57, pp. 290-301, 2012.

[13] A. Kumar and B. M. Suman, "Experimental evaluation of insulation materials for walls and roofs and their impact on indoor thermal comfort under composite climate," Build. Environ., vol. 59, pp. 635-643, 2013.

[14] E. A. B.M. Suman, R.K. Srivastava, "Experimental investigation on role of roof insulation of thermal comfort in building," in Experimental investigation on role of roof insulation of thermal comfort in building, 2007, pp. 117-122.

[15] J. R. W. R. Lu Aye, W.W.S. Charters, A.M. Fandino, "Thermal performance of sustainable energy features," Sol. Energy, pp. 1-10, 2005.

[16] A. Synnefa, M. Santamouris, and H. Akbari, "Estimating the effect of using cool coatings on energy loads and thermal comfort in residential 
buildings in various climatic conditions," Energy Build., vol. 39, no. 11, pp. 1167-1174, 2007.

[17] V. Cheng, E. Ng, and B. Givoni, "Effect of envelope colour and thermal mass on indoor temperatures in hot humid climate," Sol. Energy, vol. 78, no. 4 SPEC. ISS., pp. 528-534, 2005.

[18] Building Environment and Energy Conservation, Explanation of energy consumption calculation method in housing business building criteria. .

[19] Imperial Hospital Editorial Department, New detail map. 2017.

[20] Ninomiya Book Store Editor, Detailed contemporary map.

[21] Meteorological Agency. .

[22] Ansi/Ashrae, “ANSI/ASHRAE 55:2004 Thermal Environmental Conditions for Human Occupancy," Ashrae, vol. 2004, p. 30, 2004.

[23] "http://www.nozawakobe.co.jp/product/product03.html.".

[24]“http://www.iny.jp/regulation/energy/seinou_hikaku/ materials.html.". [25]"https://wenku.baidu.com/view/7b55a8365a8102d27 6a22f3d.html.".

[26] "http://standardproject.net/smarthouse/remodeling/floor/wood/o ak.html.".

[27]"https://www.nichiha.co.jp/pro/pdf/nintei/betten/PC0 30BE-

3126.pdf?PHPSESSID=gfh1lvuc690gaqseeqvf2 n58h0.”.

[28] EnergyPlus, "Input Output Reference," Bigladder Softw., no. c, p. 2109, 2015.

[29] Japan Floor Heating Association. .

[30] R. and A.-C. E. (ASHRAE) American Society of Heating, American Society of Heating, Refrigerating and Air-Conditioning Engineers (ASHRAE), 1997. 1997.

[31] ISO 7730, Ergonomics of the thermal environment - Analytical determination and interpretation of thermal comfort using calculation of the PMV and PPD indices and local thermal comfort criteria,2005 